\title{
Statistical Specifications and Diverse Tests of Efficiency in European Foreign Exchange Markets
}

\author{
Augustine C. Arize ${ }^{1}$, Ioannis N. Kallianiotis ${ }^{2}$, Krishna M. Kasibhatla ${ }^{3}$, Scott Liu ${ }^{4} \&$ John Malindretos ${ }^{5}$ \\ ${ }^{1}$ Regents Professor of Business Administration and MIS Department, College of Business and Technology, \\ Texas A\&M, USA \\ ${ }^{2}$ Economics and Finance Department, The Arthur J. Kania School of Management, University of Scranton, USA \\ ${ }^{3}$ Department of Economics, School of Economics and Business, North Carolina A\&T State University, USA \\ ${ }^{4}$ Associate Dean and Director of International Programs, New York Institute of Technology, USA \\ ${ }^{5}$ Department of Economics, Finance and Global Business, Cotsakos College of Business, William Paterson \\ University, USA
}

Correspondence: John Malindretos, Department of Economics, Finance and Global Business, Cotsakos College of Business, William Paterson University, USA. E-mail: MALINDRETOSJ@wpunj.edu

Received: April 30, 2015

doi:10.5539/ijef.v7n10p235
Accepted: August 4, 2015

Online Published: September 25, 2015

URL: http://dx.doi.org/10.5539/ijef.v7n10p235

\begin{abstract}
This paper uses an efficiency specification model of the spot and forward foreign exchange markets and tests the random walk, the general efficiency, and the unbiasedness hypotheses (the forward rate usually being viewed as an unbiased predictor of the future spot rate) by utilizing a regression estimation and many different specification and diagnostic tests for the series and the error terms (residuals). The random walk hypothesis cannot be rejected. The unbiased forward rate hypothesis has failed to be rejected in Germany, Belgium, and the Netherlands even though more research is needed in this area so as to have better statistical inferences available.
\end{abstract}

\section{Introduction}

Economists claim that the forward exchange rate will be an unbiased predictor of the future spot rate when markets are efficient and expectations rational (correct on average). And which market is, then, called efficient? According to Fama (1970), a market in which prices always "fully reflect" available information is called "efficient." But economists have not reached agreement yet even on major economic issues. The allocation of ownership of the economy's capital stock, and resources in general, is a very difficult task that economists have yet to resolve. So far, we have just depended on the markets and the price mechanism that our economic system perceives as ideal. All our models today assume that market efficiency exists. But is this true? An understanding of market efficiency and an improvement of its disefficiency are important to government policymakers, central bankers, multinational financial managers, and international investors. Market behavior is of greatest importance to government policymakers so they can design the appropriate macro-policy for achieving the goals of efficient resource allocation, steady growth, full employment, price stability, and improvement of the welfare of their fellow citizens.

Samuelson and Nordhaus (1985) defined an efficient market as one where all new information is quickly understood by market participants and becomes immediately incorporated into market prices. This efficient markets hypothesis has been extensively developed in the domestic finance literature. Its importance is due to the fact that, if the market is efficient, the current price of an asset will fully reflect available information with regard to its valuation. The prices of financial assets thus provide signals for portfolio allocation. But is this "available information" the full information that human beings must have?

In addition to domestic finance, the hypothesis of efficiency has been used in many studies of the foreign exchange market. This hypothesis suggests that there are no unexploited profit opportunities. In the foreign exchange market, this implies that the forward rate summarizes all relevant and available information useful for forecasting the future spot rate. Analyzing this aspect of efficiency requires an equilibrium model of pricing in the foreign exchange market. Consequently, any empirical test of efficiency is a joint test of efficiency (full 
information) and the equilibrium (harmony) model. (By "equilibrium," we mean an internal, external, and global balance that exists in markets and societies because we (every individual) are in balance and live in harmony with ourselves and others; otherwise, how can there be an equilibrium? Regarding what we mean by a set of full information, see the definition given below.) The hypothesis of market efficiency in the foreign exchange rate states that, in general, the expected value of the future spot rate is the current forward rate (Hakkio, 1981).

Recent tests conducted by Hansen and Hodrick (1980, 1983), Fama (1984), and Domowitz and Hakkio (1985) show that the evidence supporting the unbiased forward rate hypothesis is quite weak. They found that a nonconsistent risk premium is present in several major foreign exchange markets. The implication of these empirical findings is that one cannot use the forward rate directly as a measure for the future spot rate.

Robichek and Eaker (1978) concluded in their study that the forward rate is a biased predictor of the future spot rate and that speculative positions do not receive a return above that expected in the CAPM framework. On the other hand, Chiang's (1988) empirical analysis based on the full-sample estimation for the period January 1974 to August 1983 confirms the unbiased forward rate hypothesis for Canada, France, West Germany, and the United Kingdom. However, his evidence from the Brown-Durbin-Evans test and the Chow test cannot support the constant coefficient hypothesis in the exchange rate regression model. Also, his empirical results from the subsample study using joint-rolling regressions reject the unbiasedness hypothesis in most cases. Leachman and El Shazly (1992) found empirical evidence supporting the efficiency criterion in four out of five countries, but Chan, Gup, and Pan's (1992) results show that currency futures markets are multi-market inefficient and the currency futures prices appear to be a random walk. Finally, Hopper's (1994) answer to the question of market efficiency is -- maybe.

In this paper, we start from an equilibrium state in the foreign exchange markets and we try to study the dynamics of the stochastic coefficients of the model used to test the unbiased efficiency hypothesis. At the same time, we perform statistical and time series tests for the variables of the model as well as many diagnostic tests for the underlying assumptions and the adequacy of the specification of the model.

The paper is organized as follows. In the next section, the model is developed. The third section provides some basic statistics of the variables of the model. The fourth section gives the empirical results. The section after deals with the different specifications and diagnostic testing of the model. The last section gives a summary and the concluding remarks.

\section{The Derivation of the Basic Model}

The notion of market efficiency is usually associated with the rationality of market expectations. Our way to examine this issue is to determine whether market participants could systematically earn an excess profit. In the foreign exchange markets, the current prices reflect all available information. The efficient market approach in conjunction with rational expectations implies that economic agents' expectations about future values of exchange rate determinants are fully reflected in the forward rates. Under these circumstances, the investor cannot earn an unusual profit by exploiting the available information.

The assumptions that the conditions of market equilibrium can be stated in terms of expected returns and that equilibrium expected returns are formed on the basis of the full information set IIt are such that there are no systematic unexploited profits over time and no irrationality. Following Fama (1970), Mishkin (1983), and Levich (1985), we can state:

$$
E\left[R_{t+1}-R_{t+1}^{e} \mid I I_{t}\right]=0
$$

where $R_{t+1}^{e}$ is the expectation derived from the one-period-ahead forecast of the actual value of asset returns $R_{t+1}$ and $\mathrm{E}$ is the expectations operator conditioned on the information set $\mathrm{II}_{\mathrm{t}}$ available at the end of time

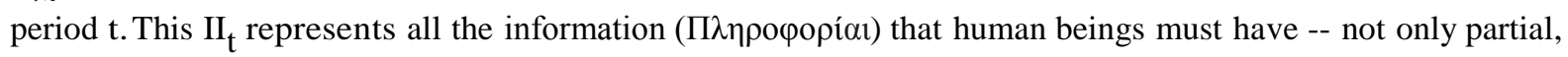
sectorial, and secular information (knowledge) about market conditions but much broader, complete, complex, and correct global information (wisdom). Our information set today is $I_{t}$, a subset of $I I_{t}, I_{t} \subset I_{t}$.

Furthermore, we are in an informational disequilibrium or an informational discord that has created enormous social cost and distress in modern times. The public forms its expectations by using $I_{t}$ instead of $I I_{t}$ and damages the economy. The role of academics is to teach the public and the role of public policy is to set and achieve social objectives. But the ideal situation for the Fed would be to have complete knowledge of the economy's structure and of all the random events that might impact it. If the Fed had an attainable objective, it could set its policies 
accordingly and achieve that goal. Some people believe that Federal Reserve officials have a sort of second sight that they use to foretell the future. But the truth is that the best economic forecasting is second rate when compared to the public's expectation. No one understands the economy's structure with enough precision to keep it perpetually humming along in balance and at top speed. Unfortunately, policymakers necessarily rely on second-best solutions. (Federal Reserve Bank of Cleveland, 1994, p. 1).

The hypotheses that the exchange rate follows a random walk process and the forward rate is an unbiased predictor of the future spot rate can be derived by using the following international parity conditions:

Purchasing Power Parity

Fisher Effect (where $\Delta p_{t}^{e}=p_{t+1}^{e}-p_{t}=p_{t}^{e}$ )

$$
s_{t}=p_{t}-p_{t}^{*}
$$

$$
\begin{aligned}
i_{t} & =r_{t}+\Delta p_{t}^{e} \\
i_{t}{ }^{*} & =r_{t}^{*}+\Delta p_{t}^{{ }^{*}{ }^{*}}
\end{aligned}
$$

Assumption

Interest Rate Parity

$$
r_{t}=r_{t}^{*}
$$

\section{International Fisher Parity}

$$
i_{t}-i_{t}^{*}=f_{t}-s_{t}
$$

$$
i_{t}-i_{t}^{*}=s_{t+1}^{e}-s_{t}
$$

where notations expressed in lowercase letters are natural logarithms, with the only exception being the interest rates; $S_{t}$ and $f_{t}$ are the spot and forward exchange rates, respectively; $i_{t}$ and $r_{t}$ are the nominal and real rates of interest, respectively; and $p_{t}$ denotes price level, regarding which an asterisk refers to the foreign country, $\Delta$ means a change of the variable, superscript e denotes market expectations, and subscripts $t, t+1$, and $t-1$ denote current, future and past periods, respectively.

Taking the mathematic expectation of eq. (7) and substituting eqs. (3) and (4), assuming also that $\Delta p_{t}^{e}=\Delta p_{t}^{* e}=0$ and that eq. (5) holds, we have

$$
s_{t+1}^{e}=E\left(s_{t+1} \mid I I_{t}\right)=i_{t}-i_{t}^{*}+s_{t}=r_{t}+\Delta p_{t}^{e}-\left(r_{t}^{*}+\Delta p_{t}^{*}\right)+s_{t}=s_{t}
$$

Substituting equation (8) into equation (1), we obtain

$$
\mathrm{E}\left[\mathrm{s}_{\mathrm{t}+1}-\mathrm{s}_{\mathrm{t}} \mid \mathrm{II}_{\mathrm{t}}\right]=0
$$

or

$$
E\left[s_{t+1}-s_{t} \mid I_{t}\right] \cong 0
$$

Equation (10) suggests that if the market is efficient then the current price of a currency will reflect all available information. The unexpected change in the spot rate, $S_{t+1}-S_{t}$, is essentially caused by the random shock $\varepsilon_{t+1}$, which hits the market between time $\mathrm{t}$ and time $\mathrm{t}+1$. Market rationality suggests that the investor finds no particular pattern from the history of $\varepsilon_{t+1}$ The well known random walk hypothesis, given as $S_{t+1}-S_{t}=\varepsilon_{t+1}, \mathrm{E}\left(\varepsilon_{t+1}\right)$ $=0, \mathrm{E}\left(\varepsilon_{t+1}^{2}\right)=\sigma^{2}$, provides a good economic reason to explain the erratic behavior of exchange rate movements. Specifically, exchange rates respond to surprises, to news, and to human actions due to ignorance of IIt and knowledge of It only. But these surprises are unpredictable. Because exchange rates respond sensitively to the unexpected events that randomly hit markets, exchange rates themselves also move randomly. This is the nature of market efficiency and has unfortunately become our second nature, too. See Mussa (1979), Rogoff (1983), Huang (1984), and Chiang (1986).

By forwarding eq. (2) for one period and taking the mathematic expectation, adding and subtracting $r_{t}$, and substituting the relationship into eqs. (2), (3), and (5), we receive: 


$$
E\left(s_{t+1}\right)=p_{t}+\Delta p_{t}^{e}-\left(p_{t}{ }^{*}+\Delta p_{t}{ }^{* e}\right)=p_{t}+\Delta p_{t}^{e}-\left(p_{t}{ }^{*}+\Delta p_{t}{ }^{* e}\right)+r_{t}-r_{t}{ }^{*}=p_{t}-p_{t}{ }^{*}+r_{t}+\Delta p_{t}{ }^{e}-\left(r_{t}{ }^{*}+\Delta p_{t}{ }^{* e}\right)=s_{t}+i_{t}-
$$

Substituting equation (11) into equation (1), we obtain:

$$
E\left[s_{t+l}-f_{t} \mid I I_{t}\right]=0
$$

or

$$
E\left[s_{t+l}-f_{t} \mid I_{t}\right] \cong 0
$$

In eq. (13), the notion of rational expectations with no risk premium is formally expressed and is usually called the "simple efficiency" hypothesis. It has been argued that the forward rate may also contain a risk premium, $\mathrm{RPt}+1$, if the economic agents are assumed to be risk averse. This relationship can be specified algebraically as:

$$
E\left[s_{t+1}-f_{t} \mid I_{t}\right]=-R P_{t+l}
$$

Equation (14) has been called the "general efficiency" hypothesis. This risk premium exists due to the unexpected part of the exchange rate $\mathrm{U}\left(\mathrm{s}_{t+1}\right)$ because $\mathrm{s}_{\mathrm{t}+1}=\mathrm{E}\left(\mathrm{s}_{\mathrm{t}+1}\right)+\mathrm{U}\left(\mathrm{s}_{\mathrm{t}+1}\right)$. What we call innovations, surprises, or "news" are the differences between the actual and expected values of some macro-variables, i.e., $\mathrm{RP}_{\mathrm{t}+1}=\left(\mathrm{i}-\mathrm{i}^{*}\right)_{\mathrm{t}+1}$ $\mathrm{E}\left(\mathrm{i}-\mathrm{i}^{*}\right)_{\mathrm{t}+1}$ (Frenkel, 1981).

First, we are testing eqs. (10), (13), and (14) as following:

$$
\begin{gathered}
s_{t}=\alpha_{0}+\alpha_{1} s_{t-1}+\varepsilon_{1 t} \\
s_{t}=\beta_{0}+\beta_{1} f_{t-1}+\varepsilon_{2 t} \\
s_{t}=\gamma_{0}+\gamma_{1} s_{t-1}+\gamma_{2} f_{t-1}+\varepsilon_{3 t} \\
s_{t}=\delta_{0}+\delta_{1} f_{t-1}+\delta_{2}\left[(i-i *)_{t}-E_{t-1}\left(i-i^{*}\right)_{t}\right]+\varepsilon_{4 t}
\end{gathered}
$$

The unbiased efficiency hypothesis is assumed to hold if: $\alpha_{0}=\beta_{0}=\Upsilon_{0}=\delta_{0}=0, \alpha_{1}=\beta_{1}=\delta_{1},{ }^{\prime} \Upsilon_{1}+{ }^{\prime} \Upsilon_{2}=1$, and $\delta_{2}$ $=0$; the relationship between $\mathrm{s}_{\mathrm{t}}$ and $\mathrm{s}_{\mathrm{t}-1,1}, \mathrm{f}_{\mathrm{t}-1}$ and "news" is linear; the $\mathrm{s}_{\mathrm{t}}{ }^{\prime} \mathrm{s}, \mathrm{f}_{\mathrm{t}}$ 's, and "news" are nonrandom variables whose values are fixed, and $\sigma_{\text {st }}^{2} \neq 0, \sigma_{\text {ft }}^{2} \neq 0, \sigma^{2}$ "news" $\neq 0$ and finite; and $\mathrm{E}\left(\varepsilon_{t}\right)=0, \mathrm{E}\left(\varepsilon_{t}^{2}\right)=\sigma^{2}$, and $\mathrm{E}\left(\varepsilon_{t}\right.$, $\left.\varepsilon_{t-1}\right)=0$, meaning that $\varepsilon_{1 t}, \varepsilon_{2 t}, \varepsilon_{3 t}$, and $\varepsilon_{4 t}, \sim \mathrm{N}\left(0, \sigma^{2}\right)$.

\section{Simple Testing of the Model and Basic Statistics}

The data include monthly figures for the spot and forward rate of the U.S. dollar (\$) with respect to the Belgian franc (BF), the Dutch guilder (Fl), and the (West) German Deutschemark (DM) and U.S. Treasury bill rates (of three months) or other interest rates. All data come from Main Economic Indicators, OECD and cover the period March 1973 to June 1994.

First, we started testing the random walk hypothesis by calculating the mean value, the variance, and the coefficient of variation of the error term $\left(\varepsilon_{t}\right)$. The results appear in Table 1. As we see, the $\mathrm{E}\left(\varepsilon_{t}\right)$ is small and the variance is small but it is not constant over time. Then, the general efficiency hypothesis was tested and in Table 2 the results are presented. Table 3 shows the correlation matrix for the exchange rates. In Table 4, some basic statistics are provided. (See Kallianiotis (1991) for a detailed discussion of all these statistics and for other formal time series tests.) These statistics are mean values, standard deviations, maximum, minimum, skewness, kurtosis, correlation, normality test statistics, autocorrelation and partial autocorrelation, cross correlation, and, finally, unit roots (stationary) tests.

Table 1. Testing of random walk hypothesis: $s_{t+1}-s_{t}=\varepsilon_{t+1}, \mathrm{E}\left(\varepsilon_{t+1}\right)=0, \mathrm{E}\left(\varepsilon_{t+1}^{2}\right)=\sigma^{2}$

\begin{tabular}{lcccc}
\hline Country & $\mathrm{E}\left(\boldsymbol{\varepsilon}_{t}\right)$ & $\mathrm{E}\left(\varepsilon_{t}^{2}\right)$ & $\sigma^{2}$ (constant) & $\mathrm{CV}$ \\
\hline Belgium & .0007 & .001 & NO & 45.1753 \\
Netherlands & .002 & .001 & NO & 15.8114 \\
Germany & .002 & .001 & NO & 15.8114 \\
\hline
\end{tabular}

Note. Data from 1973.03 to 1994.06 . 
Table 2. Testing of the "general efficiency" hypothesis: equation (14)

\begin{tabular}{lcccccr}
\hline & \multicolumn{7}{c}{$E\left[s_{t+1}-f_{t} \mid \mathrm{I}_{t}\right]=-\mathrm{RP}_{\mathrm{t}+1}$} \\
\cline { 2 - 7 } & $\mathrm{RP}_{\mathrm{t}}$ & $\sigma_{\mathrm{RPt}}$ & $\mathrm{RP}_{\mathrm{t}+1}$ & $\sigma_{\mathrm{RP}+1}$ & $\mathrm{RP}_{\mathrm{t}+3}$ & $\sigma_{\mathrm{RP}+2}$ \\
\hline Belgium & .003 & .00005 & .004 & .001 & .006 & .004 \\
Netherlands & -.005 & .00009 & -.002 & .001 & .003 & .004 \\
Germany & -.005 & .00008 & -.003 & .001 & .002 & .004 \\
\hline
\end{tabular}

Note. The forward rates are the three-month forward rates, then

$\begin{array}{cccc}0 & 1 & 2 & 3 \\ \mathrm{~F}_{\mathrm{t}} & \mathrm{S}_{\mathrm{t}+1} & \mathrm{~S}_{\mathrm{t}+2} & \mathrm{~S}_{\mathrm{t}+3} \\ \mathrm{~S}_{\mathrm{t}} & & & \end{array}$

To predict the $S_{t}$ we must use $F_{t}$ (best predictor because $\sigma_{\mathrm{RPT}}$ is small). Then, the forward rate cannot predict the future spot rate very well (no efficiency). A negative RP means that the forward rate contains a risk premium (i.e., Netherlands and Germany). A positive RP means that the forward rate does not contain a risk premium and the investors are accepting a lower exchange rate for the safety of the forward market, meaning that they pay for the certainty of the forward market and prefer the forward market to the spot market, such as in Belgium because the spot market $\mathrm{t} h$ e $\mathrm{r}$ e contains a risk and investors require a risk premium. The risk premium in the forward market appears equally small in the Netherlands and Germany $\left(\mathrm{RP}_{\mathrm{t}}=-.005\right)$. On the other hand, the smallest risk premium in the spot market is required in Germany $\left(\mathrm{RP}_{\mathrm{t}+3}=.002\right)$ and the largest is in Belgium $\left(\mathrm{RP}_{\mathrm{t}+3}=.006\right)$. The foreign exchange market is not very efficient. The most efficient one $(\mathrm{RP} \rightarrow 0)$ is in France (1-month forward) and the least efficient one is in the U.K. because of its large risk premium (3-month forward). The most stable market $\left(\sigma_{R P} \rightarrow 0\right)$ is in Canada (current spot market, $\left.\sigma_{R P t}\right)$ and the U.K. and France equally display the most unstable markets (the largest $\sigma_{R P t}$ at $\sigma R P_{t+2}$ ).

Table 3. Correlation matrix for spot and forward exchange rates

\begin{tabular}{lcccccc}
\hline & SB & fB & SN & fN & sG & fG \\
\hline SB & 1.000 & & & & & \\
$\mathrm{fB}$ & 0.999 & 1.000 & & & & \\
$\mathrm{SN}$ & 0.833 & 0.828 & 1.000 & & & \\
$\mathrm{fN}$ & 0.856 & 0.858 & 0.999 & 1.000 & & \\
$\mathrm{sG}$ & 0.755 & 0.750 & 0.989 & 0.984 & 1.000 & 1.000 \\
$\mathrm{fG}$ & 0.759 & 0.755 & 0.988 & 0.983 & 0.999 & \\
\hline
\end{tabular}

Note. Netherlands sample range from 1973.01 to 1994.06 ,

$\mathrm{S}=$ spot exchange rate, $\mathrm{f}=$ forward exchange rate, $\mathrm{B}=\mathrm{Belgium}$,

$\mathrm{N}=$ Netherlands, $\mathrm{G}=$ Germany.

Table 4. Basic statistics of spot and forward exchange rates

\begin{tabular}{lcccc}
\hline & $\mathrm{S}_{\mathrm{B}}$ & $\mathrm{D}\left(\mathrm{s}_{\mathrm{B}}\right)$ & $\mathrm{f}_{\mathrm{B}}$ & $\mathrm{D}\left(\mathrm{f}_{\mathrm{B}}\right)$ \\
\hline Mean & .962 & .001 & .959 & .001 \\
St. Dev. & .196 & .035 & .196 & .034 \\
Maximum & 1.303 & .117 & 1.302 & .117 \\
Minimum & .400 & -.121 & .397 & -.123 \\
Skewness & -.841 & -.234 & -.824 & -.213 \\
Kurtosis & 3.227 & 4.016 & 3.216 & 3.940 \\
J-B St. & $30.694^{*}$ & $13.346^{*}$ & $29.474^{*}$ & $11.356^{*}$ \\
B-P Q-St. & $2357.20^{*}$ & 13.080 & $2356.74^{*}$ & 13.940 \\
L-B Q-St. & $2432.52^{*}$ & 13.57 & $2431.96^{*}$ & 14.440 \\
D-F t-St. & $1.886^{*}$ & $3.504^{*}$ & $1.891^{*}$ & $3.518^{*}$ \\
\hline
\end{tabular}




\begin{tabular}{lcccc}
\hline & $\mathrm{S}_{\mathrm{N}}$ & $\mathrm{D}\left(\mathrm{s}_{\mathrm{N}}\right)$ & $\mathrm{f}_{\mathrm{N}}$ & $\mathrm{D}\left(\mathrm{f}_{\mathrm{N}}\right)$ \\
\hline Mean & 3.771 & .002 & 3.732 & .002 \\
St. Dev. & .191 & .035 & .175 & .035 \\
Maximum & 4.142 & .117 & 4.076 & .122 \\
Minimum & 3.279 & -.122 & 3.285 & -.149 \\
Skewness & -.294 & -.144 & -.174 & -.154 \\
Kurtosis & 2.206 & 3.876 & 2.312 & 4.827 \\
J-B St. & $10.417^{*}$ & $9.065^{*}$ & $5.302^{*}$ & $30.612^{*}$ \\
B-P Q-St. & $2253.37^{*}$ & $10.730^{*}$ & $1655.70^{*}$ & 8.360 \\
L-B Q-St. & $2324.82^{*}$ & 11.130 & $1716.26^{*}$ & 8.690 \\
D-F t-St. & $2.151^{*}$ & $3.675^{*}$ & 1.869 & $3.264^{*}$ \\
\hline & $\mathrm{S}_{\mathrm{G}}$ & $\mathrm{D}\left(\mathrm{s}_{\mathrm{G}}\right)$ & $\mathrm{f}_{\mathrm{G}}$ & $\mathrm{D}\left(\mathrm{f}_{\mathrm{G}}\right)$ \\
\hline Mean & 3.867 & .002 & 3.871 & .002 \\
St. Dev. & .202 & .035 & .198 & .035 \\
Maximum & 4.262 & .119 & 4.247 & .115 \\
Minimum & 3.405 & -.122 & 3.413 & -.124 \\
Skewness & -.105 & -.092 & -.143 & -.087 \\
Kurtosis & 1.838 & 4.011 & 1.812 & 4.022 \\
J-B St. & $14.867^{*}$ & $11.266^{*}$ & $15.931^{*}$ & $11.466^{*}$ \\
B-P Q-St. & $2296.76^{*}$ & 10.750 & $2280.59^{*}$ & 10.680 \\
L-B Q-St. & $2370.10^{*}$ & 11.750 & $2353.24^{*}$ & 11.070 \\
D-F t-St. & $2.249 *$ & $3.742^{*}$ & $2.272^{*}$ & $3.705^{*}$ \\
\hline
\end{tabular}

Note. See previous tables; $\mathrm{D}=$ the first difference operator.

\section{The Empirical Results}

We estimate equations (15), (16), (17), and (18) by using an Ordinary Least Squares (OLS) and an Instrumental Variable (IV) method. As instruments, we use a constant, time, time squared, and lagged values of the spot and forward rates. The expected interest rate differential is computed from a regression of the interest differential on a constant, two lagged values of the interest differential, two lagged spot exchange rates, and time. The results from the estimations of those four equations are shown in Tables 5, 6, 7, and 8. The overall results are robust and we have good statistics, too.

Table 5. Regression estimates of equation (15): $s t=\alpha_{0}+\alpha_{1} s_{t-1}+\varepsilon_{1 t}$

\begin{tabular}{|c|c|c|c|c|c|c|}
\hline & $a_{0}$ & $a_{1}$ & $R^{2}$ & D-W & SSR & $\mathrm{F}$ \\
\hline \multicolumn{7}{|c|}{ Belgium } \\
\hline OLS & $\begin{array}{r}.015 \\
(.011)\end{array}$ & $\begin{array}{l}.985^{*} \\
(.011)\end{array}$ & .969 & 1.897 & .307 & 7848.35 \\
\hline IV & $\begin{array}{c}.016 \\
(.011) \\
\end{array}$ & $\begin{array}{l}.984 * \\
(.011)\end{array}$ & .969 & 1.894 & .307 & 7578.66 \\
\hline \multicolumn{7}{|c|}{ Netherlands } \\
\hline OLS & $\begin{array}{c}.061 \\
(.043)\end{array}$ & $\begin{array}{l}.984 * \\
(.011)\end{array}$ & .967 & 1.925 & .307 & 7446.37 \\
\hline IV & $\begin{array}{c}.040 \\
(.050)\end{array}$ & $\begin{array}{l}.990 * \\
(.013)\end{array}$ & .964 & 2.001 & .246 & 5537.99 \\
\hline \multicolumn{7}{|c|}{ Germany } \\
\hline OLS & $\begin{array}{c}.063 \\
(.042)\end{array}$ & $\begin{array}{l}.984 * \\
(.011)\end{array}$ & .970 & 1.893 & .310 & 8315.19 \\
\hline IV & $\begin{array}{c}.068 \\
(.042)\end{array}$ & $\begin{array}{l}.983 * \\
(.011)\end{array}$ & .970 & 1.890 & .310 & 8044.99 \\
\hline
\end{tabular}

Note. OLS=Ordinary Least Squares, IV=Instrumental Variables, *=significant at least at the 10 percent level, standard errors in parentheses. 
Table 6. Regression estimates of equation (16): $s_{t}=\beta_{0}+\beta_{1} f_{t-1}+\varepsilon_{2 t}$

\begin{tabular}{|c|c|c|c|c|c|c|}
\hline & $b_{0}$ & $b_{1}$ & $R^{2}$ & D-W & SSR & $\mathrm{F}$ \\
\hline \multicolumn{7}{|c|}{ Belgium } \\
\hline OLS & $\begin{array}{l}.020 * \\
(.011)\end{array}$ & $\begin{array}{l}.983^{*} \\
(.012)\end{array}$ & .966 & 1.770 & .331 & 7275.44 \\
\hline IV & $\begin{array}{l}.020^{*} \\
(.011) \\
\end{array}$ & $\begin{array}{l}.983 * \\
(.012) \\
\end{array}$ & .966 & 1.768 & .331 & 7036.82 \\
\hline \multicolumn{7}{|c|}{ Netherlands } \\
\hline OLS & $\begin{array}{l}-.026^{*} \\
(.014)\end{array}$ & $\begin{array}{l}1.006^{*} \\
(.004)\end{array}$ & .997 & 1.423 & .020 & 68548.70 \\
\hline IV & $\begin{array}{l}.004 \\
(.055)\end{array}$ & $\begin{array}{l}.998^{*} \\
(.015)\end{array}$ & .958 & 1.822 & .285 & 4676.21 \\
\hline \multicolumn{7}{|c|}{ Germany } \\
\hline OLS & $\begin{array}{l}-.082^{*} \\
(.010)\end{array}$ & $\begin{array}{l}1.020^{*} \\
(.003)\end{array}$ & .998 & .204 & .016 & 160556.5 \\
\hline IV & $\begin{array}{l}-.014 \\
(.045)\end{array}$ & $\begin{array}{l}1.003 * \\
(.012)\end{array}$ & .968 & 1.778 & .338 & 7352.39 \\
\hline
\end{tabular}

Note. See the previous tables.

Table 7. Regression estimates of eq. (17): $s_{t}=\Upsilon_{0}+{ }^{\prime} \Upsilon_{1} s_{t-1}+{ }^{\prime} \Upsilon_{2} f_{t-1}+\varepsilon_{3 t}$

\begin{tabular}{|c|c|c|c|c|c|c|c|}
\hline & $\Upsilon_{0}$ & $\Upsilon_{1}$ & $\Upsilon_{2}$ & $R^{2}$ & D-W & SSR & F \\
\hline \multicolumn{8}{|c|}{ Belgium } \\
\hline OLS & $\begin{array}{c}.014 \\
(.011)\end{array}$ & $\begin{array}{l}1.333^{*} \\
(.292)\end{array}$ & $\begin{array}{l}-.348 \\
(.292)\end{array}$ & .969 & 1.913 & .306 & 3931.30 \\
\hline IV & $\begin{array}{r}.016 \\
(.011) \\
\end{array}$ & $\begin{array}{l}.977 * \\
(.380) \\
\end{array}$ & $\begin{array}{l}.007 \\
(.380) \\
\end{array}$ & .969 & 1.894 & .308 & 3773.50 \\
\hline \multicolumn{8}{|c|}{ Netherlands } \\
\hline OLS & .061 & $1.456^{*}$ & $-.471^{*}$ & .964 & 2.064 & $\begin{array}{c}.24 \\
1\end{array}$ & 2846.59 \\
\hline IV & $\begin{array}{l}(.050) \\
.081 \\
(.057) \\
\end{array}$ & $\begin{array}{l}(.236) \\
2.284^{*} \\
(.680) \\
\end{array}$ & $\begin{array}{l}(.238) \\
-1.304^{*} \\
(.685) \\
\end{array}$ & .962 & 2.126 & .255 & 2600.42 \\
\hline \multicolumn{8}{|c|}{ Germany } \\
\hline OLS & $\begin{array}{l}.097^{*} \\
(.048)\end{array}$ & $\begin{array}{l}1.367 * \\
(.271)\end{array}$ & $\begin{array}{l}-.390 \\
(.276)\end{array}$ & .971 & 1.892 & .307 & 4174.88 \\
\hline IV & $\begin{array}{l}.092 * \\
(.050)\end{array}$ & $\begin{array}{r}1.245^{*} \\
(.302)\end{array}$ & $\begin{array}{l}-.267 \\
(.308)\end{array}$ & .971 & 1.892 & .307 & 4035.43 \\
\hline
\end{tabular}

Note. See the previous tables.

Table 8. Regression Estimates of eq. (18): $\mathrm{s}_{\mathrm{t}}=\delta_{0}+\delta_{1} f_{t-1}+\delta_{2}\left[\left(i-i^{*}\right)_{t}-E_{t-1}\left(i-i^{*}\right)_{t}\right]+\varepsilon_{4 t}$

\begin{tabular}{|c|c|c|c|c|c|c|c|}
\hline & $\delta_{0}$ & $\delta_{1}$ & $\delta_{2}$ & $R^{2}$ & D-W & SSR & $\mathrm{F}$ \\
\hline \multicolumn{8}{|c|}{ Belgium } \\
\hline OLS & ${ }_{(.011)}^{.027 *}$ & $\begin{array}{l}.976^{*} \\
(.011)\end{array}$ & $\begin{array}{l}-.005^{*} \\
(.011)\end{array}$ & .969 & 1.859 & .305 & 3944.32 \\
\hline IV & $\begin{array}{c}.026^{*} \\
(.011)\end{array}$ & $\begin{array}{l}.977^{*} \\
(.380)\end{array}$ & $\begin{array}{l}-.004 * \\
(.380)\end{array}$ & .969 & 1.861 & .306 & 3793.13 \\
\hline \multicolumn{8}{|c|}{ Netherlands } \\
\hline OLS & $\begin{array}{l}.024 \\
(.052)\end{array}$ & $\begin{array}{l}.993^{*} \\
(.014)\end{array}$ & $\begin{array}{l}-.004^{*} \\
(.001)\end{array}$ & .960 & 1.891 & .270 & 2534.04 \\
\hline IV & $\begin{array}{l}.005 \\
(.053) \\
\end{array}$ & $\begin{array}{l}.998^{*} \\
(.014) \\
\end{array}$ & $\begin{array}{l}-.003 \\
(.002) \\
\end{array}$ & .960 & 1.895 & .272 & 2440.18 \\
\hline \multicolumn{8}{|c|}{ Germany } \\
\hline OLS & $\begin{array}{l}.026 \\
(.045)\end{array}$ & $\begin{array}{l}.993 * \\
(.001)\end{array}$ & $\begin{array}{l}-.004 * \\
(.001)\end{array}$ & .970 & 1.847 & .318 & 4033.52 \\
\hline IV & $\begin{array}{l}.024 \\
(.046)\end{array}$ & $\begin{array}{l}.993 * \\
(.012)\end{array}$ & $\begin{array}{l}-.003 \\
(.001)\end{array}$ & .970 & 1.849 & .318 & 3900.23 \\
\hline
\end{tabular}

Note. See the previous tables. 


\section{Specifications and Diagnostic Tests of the Model}

The final equations of the model [Equations (15), (16), (17), and (18)] were subjected to general specification and diagnostic tests in order to determine the adequacy of the statistical specifications. We contacted a Wald test to test the hypothesis involving the restriction on the coefficients of the explanatory variables. Then we added an extra variable to the existing equations and asked whether this makes a significant contribution. Next, we tested the residuals of our equations, testing for serial correlation, autocorrelation and partial autocorrelation, autoregressive conditional heteroskedasticity (ARCH), and white heteroskedasticity. Finally, we did some specification and stability tests. These are a Ramsey test of specification error, Chow tests done by splitting the data into three sets, 1973.03 to 1979.05 , 1979.06 to 1985.02 , and 1985.03 to 1994.06 , a Chow forecast test by estimating the equation with the observations up to 1991.03 and predicting the values of the dependent variables in the remaining data points, and Cusum tests to examine the stability of the parameters. The results appear in Tables 9, 10, 11, and 12 below.

Table 9. Specification and diagnostic tests of equation (15)

\begin{tabular}{|c|c|c|c|}
\hline & Belgium & Netherlands & Germany \\
\hline \multicolumn{4}{|l|}{$\underline{\text { Coefficient Tests }}$} \\
\hline Wald Test & $\mathrm{F}=.929$ & $\mathrm{~F}=.298$ & $\mathrm{~F}=1.610$ \\
\hline$\left(a_{0}=0, a_{1}=1\right)$ & $x^{2}=1.859$ & $x^{2}=2.596$ & $x^{2}=3.221$ \\
\hline Add Variable & $\mathrm{F}=.502$ & $\mathrm{~F}=.125$ & $\mathrm{~F}=.645$ \\
\hline$\left(\mathrm{s}_{\mathrm{t}-2}\right)$ & $\mathrm{LR}=.508$ & $\mathrm{LR}=.126$ & $\mathrm{LR}=.652$ \\
\hline \multicolumn{4}{|l|}{$\underline{\text { Residuals Tests }}$} \\
\hline Ser. Correlation (12) & $\mathrm{F}=1.200$ & $\mathrm{~F}=.959$ & $\mathrm{~F}=.927$ \\
\hline $\mathrm{E}\left(\varepsilon_{\mathrm{t}}, \varepsilon_{\mathrm{t}-1}\right)=0$ & $\mathrm{nR}^{2}=14.376$ & $\mathrm{nR}^{2}=11.617$ & $\mathrm{nR}^{2}=11.247$ \\
\hline Auto \& Partial & $\mathrm{B}-\mathrm{P}=14.26$ & $\mathrm{~B}-\mathrm{P}=11.38$ & $\mathrm{~B}-\mathrm{P}=11.31$ \\
\hline Correlation $\varepsilon_{\mathrm{t}}(12)$ & $\mathrm{L}-\mathrm{B}=14.79$ & $\mathrm{~L}-\mathrm{B}=11.81$ & $\mathrm{~L}-\mathrm{B}=11.72$ \\
\hline \multirow[t]{3}{*}{ Normality of $t$} & $\mathrm{~S}=-.218$ & $\mathrm{~S}=-.122$ & $\mathrm{~S}=-.071$ \\
\hline & $\mathrm{K}=3.878$ & $K=3.693$ & $\mathrm{~K}=3.804$ \\
\hline & $\mathrm{J}-\mathrm{B}=10.258 *$ & $\mathrm{~J} J-B=5.760 *$ & $\mathrm{~J}-\mathrm{B}=7.107 *$ \\
\hline ARCH Test (12) & $\begin{array}{l}\mathrm{F}=.891 \\
\mathrm{nR}^{2}=10.795\end{array}$ & $\begin{array}{l}\mathrm{F}=.944 \\
\mathrm{nR}^{2}=11.406\end{array}$ & $\begin{array}{l}\mathrm{F}=.691 \\
\mathrm{nR}^{2}=8.455^{*}\end{array}$ \\
\hline White Heteroskedasticity & $\begin{array}{l}\mathrm{F}=2.965^{*} \\
\mathrm{nR}^{2}=5.863^{*}\end{array}$ & $\begin{array}{l}\mathrm{F}=2.689^{*} \\
\mathrm{nR}^{2}=5.328^{*}\end{array}$ & $\begin{array}{l}\mathrm{F}=1.530 \\
\mathrm{nR}^{2}=3.060\end{array}$ \\
\hline \multicolumn{4}{|c|}{ Specification \& Stability Tests } \\
\hline \multirow[t]{2}{*}{ Ramsey Test (1) } & $\mathrm{F}=1.580$ & $\mathrm{~F}=.980$ & ----- \\
\hline & $\mathrm{LR}=1.600$ & $\mathrm{LR}=.989$ & \\
\hline Chow Test & $\mathrm{F}=4.867 *$ & $\mathrm{~F}=4.503^{*}$ & $\mathrm{~F}=4.185^{*}$ \\
\hline Break-Point 79.05, 85.02 & $\mathrm{LR}=19.200^{*}$ & $\mathrm{LR}=17.809 *$ & $L R=16.594 *$ \\
\hline Chow Test & $\mathrm{F}=1.251$ & $\mathrm{~F}=1.308^{*}$ & $\mathrm{~F}=1.260$ \\
\hline Forecast 91.03 & $\mathrm{LR}=53.783^{*}$ & $\mathrm{LR}=56.007^{*}$ & $\mathrm{LR}=54.120^{*}$ \\
\hline Cusum Tests & $\begin{array}{l}\text {--some instability } \\
\text { in the parameters of the } \\
\text { equation } \varepsilon \mathrm{t} \sim \mathrm{N}\left(0, \sigma^{2} \mathrm{I}\right)\end{array}$ & $\begin{array}{l}\text { - some instability } \\
\text { in the parameters of the } \\
\text { equation } \varepsilon \mathrm{t} \sim \mathrm{N}\left(0, \sigma^{2} \mathrm{I}\right)\end{array}$ & $\begin{array}{l}\text { - some instability } \\
\text { in the parameters of the } \\
\text { equation } \varepsilon \mathrm{t} \sim \mathrm{N}\left(0, \sigma^{2} \mathrm{I}\right)\end{array}$ \\
\hline
\end{tabular}

Note. See the previous tables.

Table 10. Specification and diagnostic tests of equation (16)

\begin{tabular}{llll}
\hline & Belgium & Netherlands & Germany \\
\hline Coefficient Tests & & & \\
Wald Test & $\mathrm{F}=2.515^{*}$ & $\mathrm{~F}=.532$ & $\mathrm{~F}=.712$ \\
$\left(\beta_{0}=0, \beta_{1}=1\right)$ & $\mathrm{x}^{2}=5.029^{*}$ & $\mathrm{x}=1.063$ & $\mathrm{x}^{2}=1.424$ \\
Add Variable & $\mathrm{F}=.541$ & $\mathrm{~F}=.229$ & $\mathrm{~F}=.382$ \\
$(\underline{\mathrm{f}} \mathrm{t}-2)$ & $\mathrm{LR}=.547$ & $\mathrm{LR}=.232$ & $\mathrm{LR}=.386$ \\
$\underline{\text { Residuals Tests }}$ & & & \\
Ser. Correlation $(12)$ & $\mathrm{F}=1.417$ & $\mathrm{~F}=1.542$ & $\mathrm{~F}=1.659^{*}$ \\
$\mathrm{E}\left(\varepsilon_{\mathrm{t}}, \varepsilon_{\mathrm{t}-1}\right)=0$ & $\mathrm{nR}^{2}=16.803$ & $\mathrm{nR}^{2}=18.119$ & $\mathrm{nR}^{2}=19.455^{*}$ \\
\hline
\end{tabular}




\begin{tabular}{|c|c|c|c|}
\hline Auto \& Partial & $\mathrm{B}-\mathrm{P}=17.22$ & $\mathrm{~B}-\mathrm{P}=21.79^{*}$ & $\mathrm{~B}-\mathrm{P}=23.02 *$ \\
\hline Correlation $\varepsilon_{\mathrm{t}}(12)$ & $\mathrm{L}-\mathrm{B}=17.73$ & $\mathrm{~L}-\mathrm{B}=22.58^{*}$ & $\mathrm{~L}-\mathrm{B}=23.83^{*}$ \\
\hline \multirow[t]{3}{*}{ Normality of $\quad t$} & $\mathrm{~S}=-.211$ & $\mathrm{~S}=.042$ & $\mathrm{~S}=-.149$ \\
\hline & $K=3.504$ & $\mathrm{~K}=3.429$ & $K=3.618$ \\
\hline & $\mathrm{J}-\mathrm{B}=4.616^{*}$ & $\mathrm{~J}-\mathrm{B}=1.716$ & $\mathrm{~J}-\mathrm{B}=5.030^{*}$ \\
\hline ARCH Test (12) & $\begin{array}{l}\mathrm{F}=.776 \\
\mathrm{nR}^{2}=9.451\end{array}$ & $\begin{array}{l}\mathrm{F}=1.000 \\
\mathrm{nR}^{2}=12.058\end{array}$ & $\begin{array}{l}\mathrm{F}=.497 \\
\mathrm{nR}^{2}=6.143\end{array}$ \\
\hline White Heteroskedasticity & $\begin{array}{l}\mathrm{F}=2.640 * \\
\mathrm{nR}^{2}=5.233 *\end{array}$ & $\begin{array}{l}\mathrm{F}=.898 \\
\mathrm{nR}^{2}=1.805\end{array}$ & $\begin{array}{l}\mathrm{F}=2.295 \\
\mathrm{nR}^{2}=4.562\end{array}$ \\
\hline \multicolumn{4}{|c|}{ Specification \& Stability Tests } \\
\hline Ramsey Test (1) & $\begin{array}{l}\mathrm{F}=2.672 \\
\mathrm{LR}=2.708^{*}\end{array}$ & $\begin{array}{l}\mathrm{F}=.066 \\
\mathrm{LR}=.067\end{array}$ & ----- \\
\hline Chow Test & $\mathrm{F}=5.019^{*}$ & $\mathrm{~F}=6.321^{\prime} *$ & $\mathrm{~F}=7.597 *$ \\
\hline Break-Point 79.05, 85.02 & $\mathrm{LR}=19.774 *$ & $\mathrm{LR}=24.555^{*}$ & $\mathrm{LR}=29.366^{*}$ \\
\hline Chow Test & $\mathrm{F}=1.235$ & $\mathrm{~F}=.995$ & $\mathrm{~F}=1.384 *$ \\
\hline Forecast 91.03 & $\mathrm{LR}=53.177$ & $\mathrm{LR}=11.350$ & $\mathrm{LR}=58.888^{*}$ \\
\hline Cusum Tests & $\begin{array}{l}\text {--some instability } \\
\text { in the parameters of the } \\
\text { equation } \varepsilon \mathrm{t} \sim \mathrm{N}\left(0, \sigma^{2} \mathrm{I}\right)\end{array}$ & $\begin{array}{l}\text { - some instability } \\
\text { in the parameters of the } \\
\text { equation \&t } \sim \mathrm{N}\left(0, \sigma^{2} \mathrm{I}\right)\end{array}$ & $\begin{array}{l}\text { - some instability } \\
\text { in the parameters of the } \\
\text { equation } \varepsilon \mathrm{t} \sim \mathrm{N}\left(0, \sigma^{2} \mathrm{I}\right)\end{array}$ \\
\hline
\end{tabular}

Note. See the previous tables.

Table 11. Specification and diagnostic tests of equation (17)

\begin{tabular}{|c|c|c|c|}
\hline & Belgium & Netherlands & Germany \\
\hline \multicolumn{4}{|l|}{ Coefficient Tests } \\
\hline Wald Test & $\mathrm{F}=.896$ & $\mathrm{~F}=2.202$ & $\mathrm{~F}=2.623 *$ \\
\hline$\left(\gamma_{0}=0, \gamma_{1}+\gamma_{2}=1\right)$ & $\mathrm{x} 2=1.791$ & $\mathrm{x} 2=4.405$ & $\mathrm{x} 2=5.246^{*}$ \\
\hline \multirow[t]{2}{*}{ Add Variable $\left(\mathrm{s}_{\mathrm{t}-2}\right)$} & $\mathrm{F}=.294$ & $\mathrm{~F}=.293$ & $\mathrm{~F}=.586$ \\
\hline & $\mathrm{LR}=.299$ & $\mathrm{LR}=.298$ & $\mathrm{LR}=.595$ \\
\hline \multicolumn{4}{|l|}{ Residuals Tests } \\
\hline Ser. Correlation (12) & $\mathrm{F}=1.284$ & $\mathrm{~F}=1.329$ & $\mathrm{~F}=.924$ \\
\hline $\mathrm{E}\left(\varepsilon_{\mathrm{t}}, \varepsilon_{\mathrm{t}-1}\right)=0$ & $\mathrm{nR}^{2}=15.389$ & $\mathrm{nR}^{2}=15.883$ & $\mathrm{nR}^{2}=11.260$ \\
\hline Auto \& Partial & $\mathrm{B}-\mathrm{P}=15.24$ & $\mathrm{~B}-\mathrm{P}=14.80$ & $\mathrm{~B}-\mathrm{P}=11.19$ \\
\hline Correlation $\varepsilon_{t}^{(12)}$ & $\mathrm{L}-\mathrm{B}=15.83$ & $\mathrm{~L}-\mathrm{B}=15.46$ & $\mathrm{~L}-\mathrm{B}=11.59$ \\
\hline \multirow{2}{*}{ Normality of $\varepsilon_{t}$} & $\mathrm{~S}=-.214$ & $\mathrm{~S}=.049$ & $S=-.035$ \\
\hline & $\begin{array}{l}\mathrm{K}=3.969 \\
\mathrm{~J}-\mathrm{B}=11.956\end{array}$ & $\begin{array}{l}\mathrm{K}=3.668 \\
\mathrm{~J}-\mathrm{B}=11.956^{*}\end{array}$ & $\begin{array}{l}\mathrm{K}=3.895 \\
\mathrm{~J}-\mathrm{B}=11.956\end{array}$ \\
\hline ARCH Test (12) & $\begin{array}{l}\mathrm{F}=.956 \\
\mathrm{nR}^{2}=11.541\end{array}$ & $\begin{array}{l}\mathrm{F}=2.097 * \\
\mathrm{nR}^{2}=23.737 *\end{array}$ & $\begin{array}{l}\mathrm{F}=.748 \\
\mathrm{nR}^{2}=9.123\end{array}$ \\
\hline WhiteHeteroskedasticity & $\begin{array}{l}\mathrm{F}=1.463 \\
\mathrm{nR}^{2}=5.834\end{array}$ & $\begin{array}{l}\mathrm{F}=.838 \\
\mathrm{nR}^{2}=3.376\end{array}$ & $\begin{array}{l}\mathrm{F}=1.793 \\
\mathrm{nR}^{2}=7.111\end{array}$ \\
\hline \multicolumn{4}{|c|}{ Specification \& Stability Tests } \\
\hline \multirow[t]{2}{*}{ Ramsey Test (1) } & $\mathrm{F}=1.376$ & $\mathrm{~F}=.006$ & ----- \\
\hline & $\mathrm{LR}=1.397$ & $\mathrm{LR}=.006$ & \\
\hline Chow Test & $\mathrm{F}=3.251^{*}$ & $\mathrm{~F}=2.513^{*}$ & $\mathrm{~F}=2.719^{*}$ \\
\hline Break-Point 79.05, 85.02 & $\mathrm{LR}=19.457 *$ & $\mathrm{LR}=15.185^{*}$ & $\mathrm{LR}=16.375^{*}$ \\
\hline Chow Test & $\mathrm{F}=1.270$ & ----- & $\mathrm{F}=1.325$ \\
\hline Forecast 91.03 & $\mathrm{LR}=54.758^{*}$ & ---- & $\mathrm{LR}=56.898^{*}$ \\
\hline Cusum Tests & $\begin{array}{l}\text {--some instability } \\
\text { in the parameters of the equation } \\
\text { et } \sim \mathrm{N}\left(0, \sigma^{2} \mathrm{I}\right)\end{array}$ & $\begin{array}{l}\text { - some instability } \\
\text { in the parameters of the } \\
\text { equation } \varepsilon t \sim N\left(0, \sigma^{2} \mathrm{I}\right)\end{array}$ & $\begin{array}{l}\text { - some instability } \\
\text { in the parameters of the } \\
\text { equation } \varepsilon \mathrm{t} \sim \mathrm{N}\left(0, \sigma^{2} \mathrm{I}\right)\end{array}$ \\
\hline
\end{tabular}

Note. See the previous tables. 
Table 12. Specification and diagnostic tests of equation (18)

\begin{tabular}{|c|c|c|c|}
\hline & Belgium & Netherlands & Germany \\
\hline \multicolumn{4}{|l|}{ Coefficient Tests } \\
\hline \multicolumn{4}{|l|}{$\begin{array}{l}\text { Wald Test } \\
\left(\delta_{0}=\delta_{2}, \quad \delta_{1}=1\right)\end{array}$} \\
\hline \multirow{2}{*}{$\begin{array}{l}\text { Add Variable } \\
\left(\mathrm{f}_{\mathrm{t}-2}\right)\end{array}$} & $\mathrm{F}=.064$ & $\mathrm{~F}=.966$ & $\mathrm{~F}=.183$ \\
\hline & $\mathrm{LR}=.065$ & $\mathrm{LR}=.982$ & $\mathrm{LR}=.186$ \\
\hline \multicolumn{4}{|l|}{$\underline{\text { Residuals Tests }}$} \\
\hline $\begin{array}{l}\text { Ser. Correlation } \\
\mathrm{E}\left(\varepsilon_{\mathrm{t}}, \varepsilon_{\mathrm{t}-1}\right)=0\end{array}$ & $\begin{array}{l}\mathrm{F}=1.863^{*} \\
\mathrm{nR}^{2}=21.733^{*}\end{array}$ & $\mathrm{~F}=1.321 \mathrm{nR}^{2}=15.795$ & $\mathrm{~F}=1.356 \mathrm{nR}^{2}=16.191$ \\
\hline Auto \& Partial & $\mathrm{B}-\mathrm{P}=22.70^{*}$ & $\mathrm{~B}-\mathrm{P}=17.19$ & $\mathrm{~B}-\mathrm{P}=17.06$ \\
\hline Correlation $\varepsilon_{\mathrm{t}}(12)$ & $\mathrm{L}-\mathrm{B}=23.56^{*}$ & $\mathrm{~L}-\mathrm{B}=17.88$ & $\mathrm{~L}-\mathrm{B}=17.70$ \\
\hline \multirow[t]{4}{*}{ Normality of $\varepsilon_{\mathrm{t}}$} & $S=-.154$ & $\mathrm{~S}=-.241$ & $\mathrm{~S}=-.121$ \\
\hline & $\mathrm{K}=3.654$ & $\mathrm{~K}=3.604$ & $K=3.691$ \\
\hline & $\mathrm{J}-\mathrm{B}=5.581 *$ & $\mathrm{~J}-\mathrm{B}=5.354^{*}$ & $\mathrm{~J}-\mathrm{B}=5.723^{*}$ \\
\hline & $\mathrm{F}=.870 \mathrm{nR}^{2}=10.549$ & $\mathrm{~F}=.973 \mathrm{nR}^{2}=11.758$ & $\mathrm{~F}=.632 \mathrm{nR}^{2}=7.756$ \\
\hline \multicolumn{4}{|l|}{ ARCH Test (12) } \\
\hline White Heteroskedasticity & $\mathrm{F}=1.737 \mathrm{nR}^{2}=6.895$ & $\mathrm{~F}=1.326 \mathrm{nR}^{2}=5.296$ & $\mathrm{~F}=3.463 * \mathrm{nR}^{2}=13.389 *$ \\
\hline \multicolumn{4}{|l|}{ Specification \& Stability Tests } \\
\hline \multicolumn{4}{|l|}{ Ramsey Test (1) } \\
\hline Chow Test & $\mathrm{F}=4.067 *$ & $\mathrm{~F}=4.648^{*}$ & $\mathrm{~F}=5.242 *$ \\
\hline Break-Point & $\mathrm{LR}=24.118^{*}$ & $\mathrm{LR}=27.300^{*}$ & $\mathrm{LR}=30.683^{*}$ \\
\hline \multicolumn{4}{|l|}{$79.05,85.02$} \\
\hline Chow Test & $\mathrm{F}=1.269$ & $\mathrm{~F}=.931$ & $\mathrm{~F}=1.268$ \\
\hline Forecast & $\mathrm{LR}=54.716^{*}$ & $\mathrm{LR}=10.680$ & $\mathrm{LR}=54.673^{*}$ \\
\hline 91.03 & & $(90.03)$ & \\
\hline \multirow[t]{2}{*}{ Cusum Tests } & --some instability & - some instability & - some instability \\
\hline & $\begin{array}{l}\text { in the parameters of tl } \\
\mathrm{N}\left(0, \sigma^{2} \mathrm{I}\right)\end{array}$ & $\begin{array}{l}\text { - in the parameters o } \\
\text { equation } \varepsilon \mathrm{t} \sim \mathrm{N}\left(0, \sigma^{2} \mathrm{I}\right)\end{array}$ & $\begin{array}{l}\text { th in the parameters of the } \\
\text { equation } \varepsilon \mathrm{t} \sim \mathrm{N}\left(0, \sigma^{2} \mathrm{I}\right)\end{array}$ \\
\hline
\end{tabular}

Note. See the previous tables.

\section{Summary and Concluding Remarks}

In this efficiency specification model of spot and forward exchange markets, we argued that the forward rate fully reflects the limited available information (due to the lack of complete and correct global knowledge) about the exchange rate expectations and the forward rate. Thus, it is usually viewed by the market as an unbiased predictor of the future spot rate. The conventional test of the unbiasedness hypothesis that we used was a regression estimation by fitting the current spot on the one-period lagged spot rate, on the one-period lagged forward rate, on the one-period lagged spot and forward rate, and on the one-period lagged forward rate and the "news" (the difference between actual and expected interest differential). These tests involve the joint hypothesis that the constant terms do not differ from zero, that the coefficients on the one-period lagged spot and forward rates do not significantly differ from one, that the sum of the coefficients of the one period lagged spot and forward rates do not significantly differ from one, that the coefficient of the "news" is not different from zero, and that the error terms pass some statistical tests (serial correlation, normality, ARCH, etc.).

We cannot reject the unbiased hypothesis for Belgium, the Netherlands, and Germany. The results imply that we can use the forward rate as a proxy for the prediction of the spot rate next period. There is some instability in the parameters of almost all the equations of the model, but, from a forecasting point of view, this is consistent with the least cost approach to the economic agents, although it may not yield the minimum forecast error due to interventions, incomplete and partial knowledge (incorrect information), and simplicity in modeling. The overall results show that the foreign exchange markets for both the Netherlands and Germany are pretty efficient. Belgium's market efficiency is questionable. Also, Belgium's spot rate follows a random walk but its variances are not constant.

\section{Acknowledgements}

We would like to acknowledge the research assistance provided by Anton Boutchev, Kwan Cheung, and Charles Berendt. 


\section{References}

Chan, K. C., Benton, E. G., \& Ming-Shiun, P. (1992). Market Efficiency and Cointegration Tests for Foreign Currency Futures Markets. Journal of International Financial Markets, Institutions \& Money, 2(1), 79-89.

Chiang, T. (1986). Empirical Analysis on the Predictors of the Future Spot Rates. Journal of Financial Research, 9(2), 153-162. http://dx.doi.org/10.1111/j.1475-6803.1986.tb00444.x

Domowitz, I., \& Hakkio, C. S. (1985). Conditional Variance and the Risk Premium in the Foreign Exchange $\begin{array}{lllll}\text { Market. Journal of International } & \text { Economics, } & \text { 19(1-2), }\end{array}$ http://dx.doi.org/10.1016/0022-1996(85)90018-2

Eugene, F. (1984). Forward and Spot Exchange Rates. Journal of Monetary Economics, 14(3), 319-338. http://dx.doi.org/10.1016/0304-3932(84)90046-1

Fama, E. (1970). Efficient Capital Markets: A Review of Theory and Empirical Work. Journal of Finance, 25(2), 383-417. http://dx.doi.org/10.2307/2325486

Federal Reserve Bank of Cleveland. (August 1994). Economic Trends, 1.

Frenkel, J. (1981). Flexible Exchange Rates, Prices, and the Role of 'News': Lessons from the 1970s. Journal of Political Economy, 89(4), 665-705. Retrieved from http://www.jstor.org/stable/1833030

Hakkio, C. S. (1981). Expectations and the Forward Exchange Rate. International Economic Review, 22(3), 663-678. Retrieved from http://www.jstor.org/stable/2526167

Hansen, L. P., \& Hodrick, R. J. (1980). Forward Exchange Rates as Optimal Predictors of Future Spot Rates: An Econometric Analysis. Journal of Political Economy, 88(5), 829-853. http://dx.doi.org/10.1086/260910

Hopper, G. P. (1994). Is the Foreign Exchange Market Inefficient? Business Review, 17-27. Retrieved from http://www.philadelphiafed.org/research-and-data/publications/business-review/1994/brmj94gh.pdf

Huang, R. D. (1984). Some Alternative Tests of Forward Exchange Rates as Predictors of Future Spot Rates. Journal of International Money and Finance, 3(2), 153-67. http://dx.doi.org/10.1016/0261-5606(84)90003-2

Kallianiotis, I. N. (1991). Is the U.S. Budget Deficit Harming the Financial Markets and the Overall Economy? University of Scranton, School Of Management, Research Report Series No. 9110, October, pp. 1-49.

Lars, P. H., \& Robert, J. H. (1983). Risk Averse Speculation in the Forward Foreign Exchange Markets: An Econometric Analysis Linear Models. In J. A. Frenkel (Ed.), Exchange Rates and International Macroeconomics (pp. 113-152). Chicago: University of Chicago Press.

Leachman, L. L., \& Mona, R. E. S. (1992). Cointegration Analysis, Error Correction Models and Foreign Exchange Market Efficiency. Journal of International Financial Markets, Institutions \& Money, 2(1), 57-77. http://dx.doi.org/10.1300/J282V02N01_04

Levich, R. M. (1985). Empirical Studies of Exchange Rates: Price Behavior, Rate Determination and Market Efficiency. In R.W. Jones, \& P. B. Kenen (Eds.), Handbook of International Economics II (pp. 979-1040). New York: Elsevier B.V. http://dx.doi.org/10.1016/S1573-4404(85)02010-X

Mishkin F. S. (1983). A Rational Expectations Approach to Macroeconomics. Chicago: University of Chicago Press. http://dx.doi.org/10.7208/chicago/9780226531922.001.0001

Mussa, M. (1979). Empirical Regularities in the Behavior of Exchange Rates and Theories of the Foreign Exchange Market. In K. Brunner, \& A. H. Meltzer (Eds.), Policies for Employment, Prices, and Exchange Rates (Vol. 1, pp. 9-57). Carnegie-Rochester Conference Series on Public Policy, Amsterdam: North-Holland. http://dx.doi.org/10.1016/0167-2231(79)90034-4

Robichek, A. A., \& Eaker, M. R. (1978). Foreign Exchange Hedging and the Capital Asset Pricing Model. Journal of Finance, 33(2), 1011-1018. http://dx.doi.org/10.1111/j.1540-6261.1978.tb02040.x

Samuelson, P. A., \& Nordhaus, W. D. (1985). Economics (12th ed.). New York, NY: McGraw-Hill.

Thomas, C. C. (1988). The Forward Rate as a Predictor of the Future Spot Rate: A Stochastic Coefficient Approach. Journal of Money, Credit, and Banking, 20, 212-232. http://dx.doi.org/10.2307/1992112 


\section{Copyrights}

Copyright for this article is retained by the author(s), with first publication rights granted to the journal.

This is an open-access article distributed under the terms and conditions of the Creative Commons Attribution license (http://creativecommons.org/licenses/by/3.0/). 